\title{
Kostrukcyjne sposoby zmniejszania hałasu w układach biegowych wagonów towarowych
}

\begin{abstract}
$W$ artykule przedstawiono środki konstrukcyjne zmniejszajace emisje hałasu w uktadach biegowych wagonów towarowych. Jako odpowiednik układu biegowego postużyt standardowy wózek dwuosiowy typu „Y25Lsd1”. Na jego przyktadzie pokazano jak pewne modyfikacje konstrukcji wptywaja na zmniejszenie hatasu.
\end{abstract}

\section{WSTĘP}

Transport drogowy, kolejowy i lotniczy mają wspólne problemy niekorzystnie wpływające na ludzi i środowisko naturalne. Jednym z ważniejszych jest emisja hałasu. Problemem tym od dziesiątków lat zajmują się naukowcy i konstruktorzy. Poczyniono znaczne postępy $\mathrm{w}$ jego rozwiązywaniu, ale jeszcze wiele pozostało do zrobienia. Problematyka ta nabrała jeszcze większego znaczenia po wejściu Polski do Unii Europejskiej i opracowaniu przez Europejski Komitet Normalizacyjny przepisów TSI (Technicznych Specyfikacji Interoperacyjności), obowiązujących wszystkie kraje członkowskie. Zagadnienie obejmuje około 750000 wagonów towarowych, kursujących w Europie [3]. Szacuje się, że zmniejszenie emisji hałasu w $85 \div 90$ procent wagonów towarowych dawałoby odczuwalny efekt $\mathrm{w}$ zakresie ochrony środowiska naturalnego. Kolejnym argumentem przemawiającym za redukcją hałasu w wagonach towarowych są przyszłe zamiary zwiększenia długości pociagów oraz zwiększenia prędkości. Poszczególne koleje członkowskie uważaja, że środki konstrukcyjne zmniejszające emisję hałasu muszą również podjąć instytucje zajmujące się infrastrukturą kolejową. Obecnie wagony towarowe należą do najgłośniejszych pojazdów kolejowych i osiagają podczas przejazdu poziom emisji hałasu dochodzący do $100 \mathbf{d B}(\mathbf{A})$. Jak podaje Światowa Organizacja Zdrowia dopuszczalną wartością hałasu jest 65 dB(A) w dzień oraz 55 $\mathrm{dB}(\mathrm{A})$, a nawet $45 \mathrm{~dB}(\mathrm{~A}) \mathrm{w}$ porze nocnej. $\mathrm{Z}$ kolei $\mathrm{z}$ danych statystycznych wynika, że np. w Niemczech ok. 12 milionów ludzi jest narażonych na hałas przewyższający 65dB(A), przy czym największym źródłem jest hałas pochodzący od transportu szynowego [4]. Dla porównania dominujący hałas wytwarzany przez lokomotywy powstaje przy małych prędkościach oraz przy dużych prędkościach jako hałas aerodynamiczny [2]. Najistotniejszym źródłem hałasu, obciążającym środowisko naturalne jest hałas toczny. Jest on spowodowany przez drgania w układzie koło-struktura toru kolejowego, co z kolei powodują nierówności w układzie koło-szyna. Prostym zabiegiem konstrukcyjnym, zmniejszającym poziom emisji hałasu, zaaprobowanym przez UIC jest zastosowanie hamulców tarczowych. Jednak z uwagi na ich wyższe koszty, koleje wstrzymują się od ich powszechnego stosowania. Z tego wynika, że należy zachować konstrukcję układu biegowego, stosując środki, które nie naruszaja zasady zamienności zgodnie z kartą UIC 510-1 [13]. Duży wpływ na zastosowane środki konstrukcyjne, które obniżają poziom hałasu, ma rachunek ekonomiczny, którego podstawy wywodzą się z raportu ORE/ERRI B12/Rp.17[21], formułującego następujące wytyczne, obowiązujące przy produkcji wagonów towarowych:

- skoncentrowana produkcja części zamiennych, aby osiagnąć zmniejszenie ceny poprzez produkcję $\mathrm{w}$ długich seriach oraz zmniejszenie ilości narzędzi

- przygotowanie części zamiennych

- ekonomiczna organizacja napraw wagonów towarowych, polegająca na zmniejszeniu ilości modeli dla części konstrukcyjnych i części zamiennych.

\section{2. ŚRODKI KONSTRUKCYJNE ZMNIEJSZA- JĄCE EMISJĘ HAŁASU}

\subsection{WYMAGANIA DOTYCZACE EMISJI HA- LASU WG PRZEPISÓW TSI [19]}

Hałas emitowany przez wagony towarowe można podzielić na hałas przejazdu oraz hałas stacjonarny. Na hałas przejazdu wagonu towarowego duży wpływ ma hałas toczenia (hałas koło/szyna), który zależy od prędkości. Sam hałas toczenia jest powodowany przez łączną chropowatość koła i szyny oraz charakterystykę dynamiczną toru i zestawu kołowego. Zbiór parametrów dla charakterystyki hałasu przejazdu zawiera: 
Wartości dopuszczalne $\mathrm{L}_{\mathrm{p}, \mathrm{Aeq}}, \mathrm{Tp}_{\mathrm{p}}$ dla halasu przejazdu wagonów towarowych Tabela1

\begin{tabular}{|c|c|c|}
\hline L.p. & Wagony & $\mathbf{L}_{p, \mathbf{A e q}, \mathbf{T p}}$ \\
\hline 1 & $\begin{array}{l}\text { Nowe wagony o średniej liczbie osi na jednostkę długości (o/d) do } 0,15 \mathrm{~m}^{-1} \\
\text { przy prędkości } 80 \mathrm{~km} / \mathrm{h}\end{array}$ & $\leq 82 \mathrm{~dB}(\mathrm{~A})$ \\
\hline 2 & $\begin{array}{l}\text { Odnowione lub zmodernizowane wagony zgodnie } \mathrm{z} \text { art.14 ust.3 dyrektywy } \\
\text { 2001/16/WE o średniej liczbie osi na jednostkę długości (o/d) do } 0,15 \mathrm{~m}^{-1} \mathrm{przy} \\
\text { prędkości } 80 \mathrm{~km} / \mathrm{h}\end{array}$ & $\leq 84 \mathrm{~dB}(\mathrm{~A})$ \\
\hline 3 & $\begin{array}{l}\text { Nowe wagony o średniej liczbie osi na jednostkę (o/d) od powyżej } 0,15 \mathrm{~m}^{-1} \mathrm{do} \\
0,275 \mathrm{~m}^{-1} \text { przy prędkości } 80 \mathrm{~km} / \mathrm{h}\end{array}$ & $\leq 83 \mathrm{~dB}(\mathrm{~A})$ \\
\hline 4 & $\begin{array}{l}\text { Odnowione lub zmodernizowane wagony zgodnie } \mathrm{z} \text { art.14.ust.3 dyrektywy } \\
2001 / 16 / \mathrm{WE} \text { o średniej liczbie osi na jednostkę długości (o/d) od powyżej } \\
0,15 \mathrm{~m}^{-1} \text { do } 0,275 \mathrm{~m}^{-1} \text { przy prędkości } 80 \mathrm{~km} / \mathrm{h}\end{array}$ & $\leq 85 \mathrm{~dB}(\mathrm{~A})$ \\
\hline 5 & $\begin{array}{l}\text { Nowe wagony o średniej liczbie osi na jednostkę długości (o/d) powyżej } 0,275 \\
\mathrm{~m}^{-1} \text { przy prędkości } 80 \mathrm{~km} / \mathrm{h}\end{array}$ & $\leq 85 \mathrm{~dB}(\mathrm{~A})$ \\
\hline 6 & $\begin{array}{l}\text { Odnowione lub zmodernizowane wagony zgodne } \mathrm{z} \text { art.14 ust.3 dyrektywy } \\
2001 / 16 / \mathrm{WE} \text { o średniej liczbie osi na jednostkę długości }(\mathrm{o} / \mathrm{d}) \text { do powyżej } \\
0,275 \mathrm{~m}^{-1} \mathrm{przy} \text { prędkości } 80 \mathrm{~km} / \mathrm{h}\end{array}$ & $\leq 87 \mathrm{~dB}(\mathrm{~A})$ \\
\hline
\end{tabular}

o-liczba osi [-]

d-dlugość między zderzakami [m].

- poziom ciśnienia akustycznego, zgodnego z metodą pomiaru

- położenie mikrofonu pomiarowego

- prędkość wagonu

- chropowatość szyny

- dynamiczne zachowanie toru.

Hałas stacjonarny wagonu towarowego jest istotny jedynie wówczas, jeżeli wagon towarowy jest wyposażony w urządzenia pomocnicze takie jak grzejniki, generatory, układy chłodzenia. Dotyczy to głównie wagonów-chłodni.

Zbiór parametrów dla charakterystyki hałasu stacjonarnego wagonu towarowego zawiera:

- poziom ciśnienia akustycznego, zgodnie $\mathrm{z}$ określoną metodą pomiaru oraz położenia mikrofonu

- warunki eksploatacji.

Wartości dopuszczalne hałasu przejazdu mierzone są za pomocą ciagłego równoważnego poziomu ciśnienia akustycznego ważonego krzywą korekcyjną A, $\mathrm{L}_{\mathrm{p}, \mathrm{Aeq}, \mathrm{Tp}} \mathrm{W}$ czasie przejazdu pojazdu w odległości 7,5 m od osi toru powyżej niwelety główki szyny. Pomiary dokonywane są zgodnie z EN ISO 3095:2005 [17]; oprócz toru odniesienia, który powinien spełniać wymagania podane w załączniku A.1.4 niniejszych przepisów. Tor odniesienia musi być udostępniony w sposób „niedyskryminacyjny”.

Wartości dopuszczalne $\mathrm{L}_{\mathrm{p}, \mathrm{Aeq}, \mathrm{Tp}}$ dla hałasu przejazdu wagonów towarowych $\mathrm{w}$ warunkach określonych powyżej podano w tabeli 1.

Hałas stacjonarny opisywany jest za pomocą ciagłego równoważnego poziomu ciśnienia akustycznego ważonego względem $\mathrm{A}, \mathrm{L}_{\mathrm{p}, \mathrm{Aeq}, \mathrm{Tp}}$ zgodnie $\mathrm{z}$ EN ISO 3093:2005 [16]. Wartość dopuszczlna hałasu stacjonarnego wagonów towarowych w odległości 7,5 m od osi toru i 1,2 m powyżej górnej powierzchni szyn jest podana w tabeli 2 . Wartość dopuszczalna poziomu ciśnienia akustycznego
ważonego $\mathrm{L}_{\mathrm{p} \text {,Aeq, }} \quad$ Tabela 2

\begin{tabular}{|c|c|}
\hline Wagony & $\mathbf{L}_{\mathbf{p}, \mathbf{A e q}, \mathbf{T p}}$ \\
\hline $\begin{array}{c}\text { Wszystkie wagony } \\
\text { towarowe }\end{array}$ & $\leq 65 \mathrm{~dB}(\mathrm{~A})$ \\
\hline
\end{tabular}

2.2. Środki konstrukcyjne podjęte w układach biegowych wagonów towarowych, zmniejszających emisję halasu

Skutecznym rozwiązaniem w układach biegowych wagonów towarowych, zmniejszającym wartość emisji hałasu jest wyposażenie wózka w hamulce tarczowe. Konstrukcję wózka Y37, eksploatowanego pod wagonami towarowymi na trasach SNCF jest przedstawiona na rys. 1 .

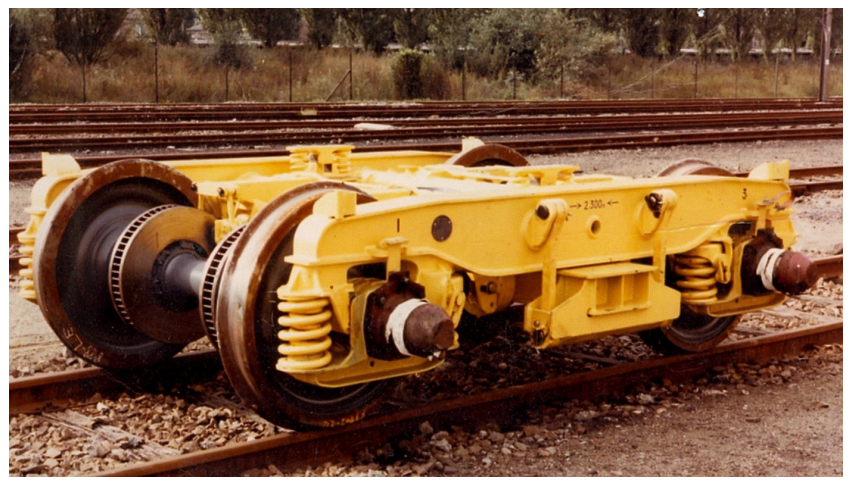

Rys.1. Wózek Y37 wagonów towarowych eksploatowany przez SNCF, wyposażony w hamulce tarczowe

Wózki te są przystosowane do prędkości $160 \mathrm{~km} / \mathrm{h}$ i obciążeń wynikających z nacisku zestawu kołowego na tor wynoszącego 18 ton cechują się niskim poziomem emisji hałasu, dzięki zastosowaniu hamulców tarczowych. Wózek ten może być po odpowiednim dostosowaniu przystosowany do ruchu z prędkością $100 \mathrm{~km} / \mathrm{h}(120 \mathrm{~km} / \mathrm{h})$ i obciążeń wynikających z nacisku zestawu kołowego na tor wynoszącego 22,5 ton (20 ton). Wytyczne do konstrukcji wózka są przed- 
stawione w raporcie Rp. ORE/ERRI B12.4 [19]. Wózki Y37 są stosowane pod wagonami platformami i wagonami krytymi o dhugich bazach (odpowiednio $\mathrm{a}_{1}=13,360 \mathrm{~m}$ oraz $\mathrm{a}_{2}=11,750 \mathrm{~m}$ ). Wózki mają charakter standardowy i są zamieszczone w karcie UIC 432 [12]. Dzięki zastosowaniu wózków wagonów towarowych typu Y37 z hamulcami tarczowymi można zmniejszyć poziom emisji hałasu o $8 \mathrm{~dB}(\mathrm{~A})$. Podobną szansę na zmniejszenie emisji hałasu mają wózki wagonów towarowych $\mathrm{z}$ hamulcami bębnowymi, które jednak nie weszły do eksploatacji komercyjnej (rys.2).

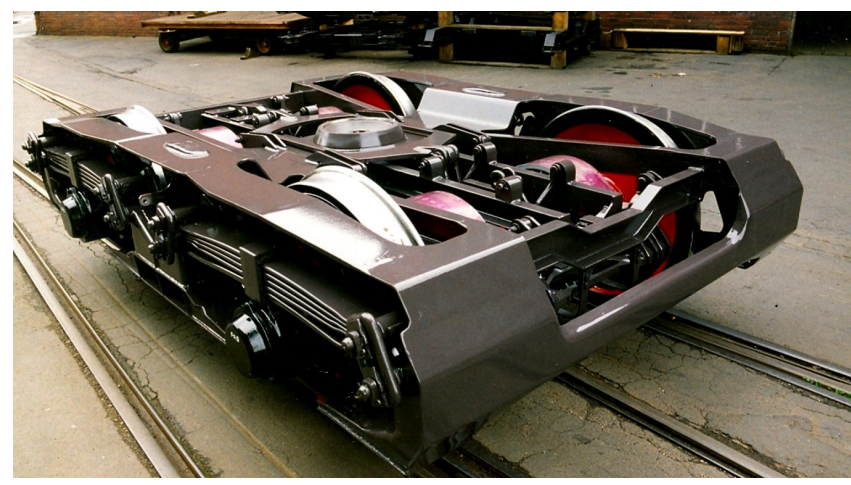

Rys.2.Wózek wagonów towarowych z hamulcami bębnowymi

Cena takich wózków jest wyższa od standardowych układów biegowych typu Y25Lsd1. Dotyczy to również wózka LEILA-DG (,LEIchtes und LärmArmes Güterwagendrehgestell) rozwijanego przez kolej niemiecką DB AG [1,5]. Pomimo wielu zalet, spełniających techniczne wymagania rynkowe $\mathrm{w}$ zakresie technicznym oraz deklarowaną emisję hałasu, wynoszącą $72 \mathrm{~dB}(\mathrm{~A})$ podczas jazdy wagonu towarowego $\mathrm{z}$ prędkością $80 \mathrm{~km} / \mathrm{h}$ istotną przeszkodą w jego wdrożeniu do produkcji seryjnej stanowi cena. Struktura cenowa poszczególnych typów wózków jest przedstawiona w tabeli 3 [1].

Zestawienie cenowe wybranych ukladów biegowych wagonów towarowych za rok 2004

Tabela 3

\begin{tabular}{|c|c|c|}
\hline L.p. & Typ wózka & $\begin{array}{c}\text { Cena układu biegowego } \\
\text { [EUR] }\end{array}$ \\
\hline 1 & $\begin{array}{c}\text { Wózek typu Y25 (bez } \\
\text { zaworu ważącego) }\end{array}$ & 10000 \\
\hline 2 & $\begin{array}{c}\text { Wózek typu Y25 z } \\
\text { zaworem ważącym }\end{array}$ & 10400 \\
\hline 3 & $\begin{array}{c}\text { Wózek standardowy DB } \\
\text { typu BA 665, BA 645, } \\
\text { BA643) }\end{array}$ & $12000 \div 15000$ \\
\hline 4 & Wózek LEILA DG & $\sim 20000$ \\
\hline
\end{tabular}

Wózki Y25Lsd1 rozpowszechnione są w większości europejskich zarządów kolejowych. Wózek jest przedstawiony na rys.3.

Jedną z istotnych różnic pomiędzy obydwoma konstrukcjami wózków wagonów towarowych, która ma decydujący wpływ na poziom emisji hałasu jest zastosowanie hamulców klockowych z żeliwa fosforowego
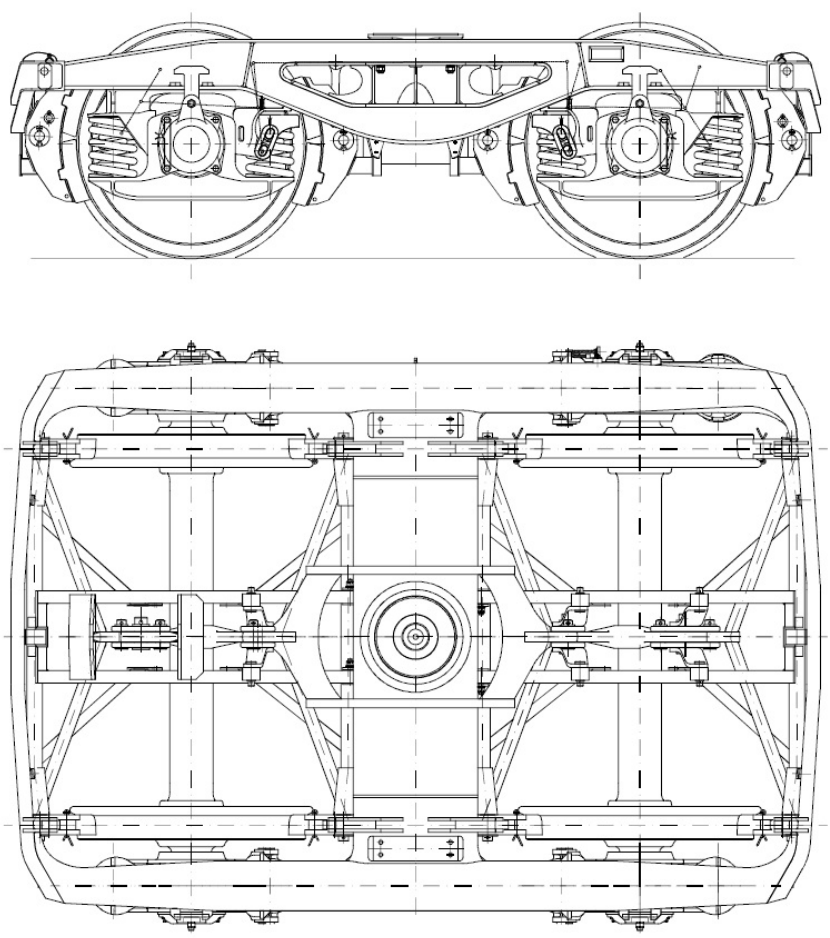

Rys.3. Wózek Y25Lsd1 dla wagonów towarowych różnego typu i przeznaczenia

o składzie chemicznym i własnościach zgodnych $\mathrm{z}$ kartą UIC 832 [16]. Jak wynika z przeprowadzonych badań oraz prac studialnych głównym źródłem hałasu jest układ koło-szyna, a decydującym parametrem jest chropowatość koła i szyny. Różnica w emisji hałasu, zarejestrowanego podczas przejazdu wagonu towarowego z kołami „gładkimi” na szynach o dużym poziomie gładkości, a emisją hałasu wagonu towarowego z układem koło-szyna o dużym poziomie emisji hałasu wynosi nawet $15 \mathrm{~dB}(\mathrm{~A})$ [3]. Każdorazowe użycie hamulca klockowego, gdzie swój udział w hamowaniu ma wstawka z żeliwa fosforowego P10 (zawartość fosforu $0,80 \% \leq \mathrm{P} \leq 1,10 \%$ ), powoduje zwiększenie chropowatości powierzchni tocznej koła, co objawia się tworzeniem „rowków” na kole. Rowki o długości $5 \mathrm{~cm}$ do $10 \mathrm{~cm}$ na powierzchni tocznej koła wytwarzają drgania o amplitudach o wielkości 10 do $300 \mu \mathrm{m}$., które przekształcają się w hałas, który jest odbierany przez ucho ludzkie.

Częstotliwość drgań można wyliczyć ze wzoru:

gdzie:

$$
f=\frac{v}{3,6 \lambda}
$$

f- częstotliwość wzbudzania w $\mathrm{Hz}$

v- prędkość jazdy w km/h

$\lambda$ - długość fali odpowiadającej chropowatości w m.

Jak wynika $\mathrm{z}$ przeprowadzonych pomiarów hałasu koło podczas jazdy pojazdu wytwarza drgania w zakresie częstotliwościowym $100 \div 5000 \mathrm{~Hz}$ w kierunku osiowym oraz w kierunku promieniowym lub ich 
kombinację.

$\mathrm{Z}$ dalszych analiz pomiarowych wynika, że chropowatość koła jest dużo większa od chropowatości szyny. Dlatego też należy zwrócić szczególną uwagę na stan koła. Jeśli główną przyczyną systematycznego zwiększania chropowatości koła jest wstawka z żeliwa fosforowego P10, to wówczas okazuje się być celowe zastosowanie wstawek z tworzyw sztucznych. W tym przypadku można wyróżnić dwa trendy rozwojowe, a mianowicie zastosowanie:

- wstawek z tworzyw sztucznych typu K

- wstawek z tworzyw sztucznych typu LL.

Zastosowanie obydwu wstawek typu K oraz LL, regulują przepisy UIC, które mają postać wytycznych $[10,11]$. Zastapienie wstawek $\mathrm{z}$ żeliwa fosforowego może w istotny sposób zmniejszyć emisję hałasu, którą szacuje się na ok. $10 \mathrm{~dB}(\mathrm{~A})$ przy prędkości 100 $\mathrm{km} / \mathrm{h}$. Wprowadzenie wstawek hamulcowych $\mathrm{z}$ tworzyw sztucznych (kompozytowych) jest związane jednak $\mathrm{z}$ rozwiązaniem wielu technicznych problemów, do których można zaliczyć:

- produkt zastępczy musi spełniać wymagania dotyczące współczynnika tarcia i zagwarantować, że podana droga hamowania jest zachowana dla każdych warunków atmosferycznych

- przy mieszanym składzie pociagu tzn. w przypadku wagonów $\mathrm{z}$ wyposażonych we wstawki $\mathrm{z}$ żeliwa fosforowego oraz wagonów wyposażonych we wstawki kompozytowe, hamowanie nie może spowodować powstania niedopuszczalnych sił wzdłużnych lub innych efektów, które wymagają specjalnych czynności od maszynisty

- prawie $25 \div 30 \%$ ciepła powstającego podczas hamowania jest odprowadzane przez wstawki z żeliwa fosforowego, natomiast reszta przez koło; materiał kompozytowy jest o wiele słabszym przewodnikiem ciepła niż żeliwo, co oznacza że większa ilość energii cieplnej musi być odprowadzona przez koło; próby eksploatacyjne przeprowadzone $\mathrm{w}$ latach osiemdziesiątych spowodowały szereg pęknięć cieplnych kół, co doprowadziło do zakazu stosowania wstawek z tworzyw sztucznych w wagonach towarowych

- łącznie produkt zastępczy nie może być droższy od dotychczas stosowanego, aby nie pogorszyć konkurencyjności transportu towarowego ładunków.

Należy zwrócić uwagę, że wstawki z żeliwa fosforowego mają szereg zalet:

- współczynnik tarcia jest prawie niezależny od warunków atmosferycznych

- gwarantują odpowiednie odprowadzenie energii cieplnej, powstałej w wyniku hamowania
- małe „płaskie miejsca” na kołach „są zeszlifowane" w wyniku następujących po sobie hamowań

- stała chropowatość powierzchni tocznej gwarantuje równomierną przyczepność.

Bardzo istotną wadą żeliwa fosforowego jest podwójna zależność współczynnika tarcia od siły docisku i prędkości, co jest przedstawione odpowiednio na rys. 4 i rys.5.

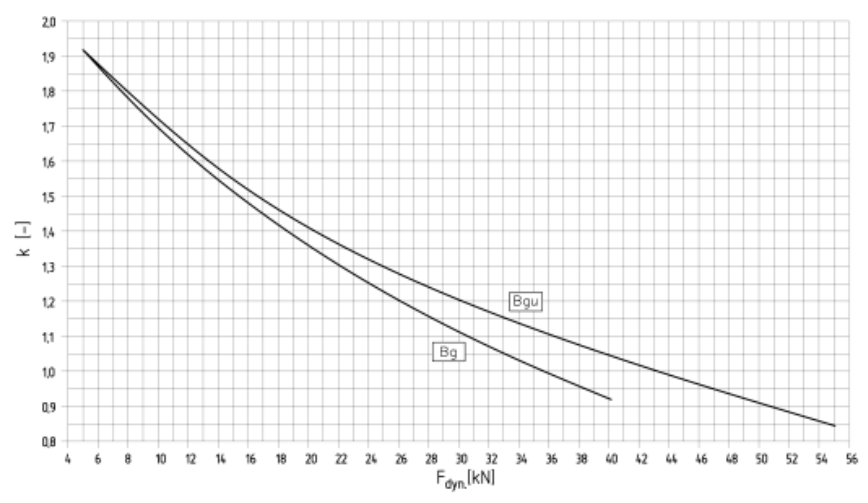

Rys.4. Zależność współczynnika tarcia żeliwa fosforowego P10 od siły docisku klocka hamulcowego do koła w trakcie hamowania wagonu towarowego wg [8]

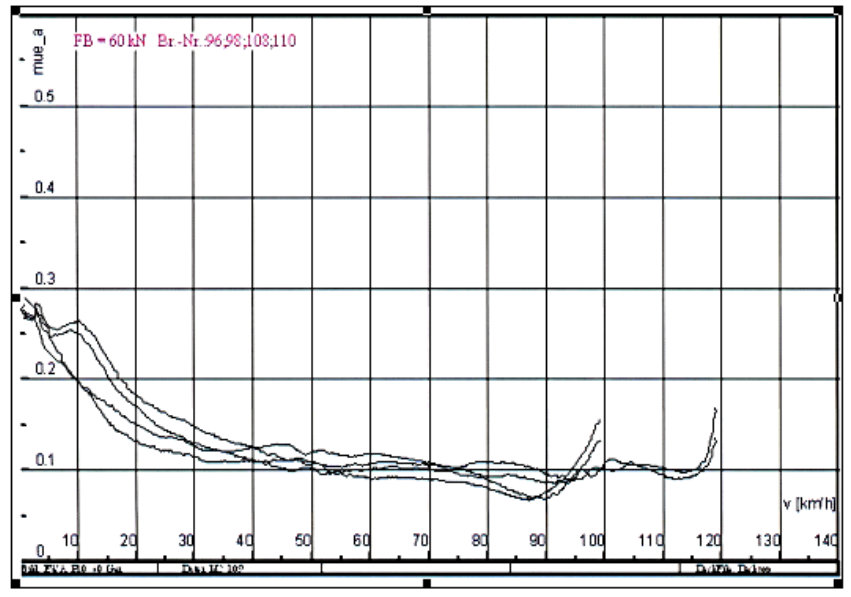

Rys.5. Zależność współczynnika tarcia żeliwa fosforowego P10 od prędkości wg [8]

Wstawki hamulcowe typu $\mathrm{K}$ mają więc większy współczynnik tarcia i do tego jego wartość jest bardziej stabilna, aniżeli dla wstawek z żeliwa fosforowego. Te wstawki można zastosować w nowych lub zmodernizowanych wagonach towarowych. Wstawki typu LL posiadają współczynnik tarcia podobny jak wstawki z żeliwa fosforowego, w wyniku czego moga one być bezpośrednio wymienione zamiast wstawek żeliwnych bez dodatkowych nakładów modernizacyjnych.

Przydatność wstawek typu K oraz LL w ramach procesu homologacji została potwierdzona przez: 
- próby stanowiskowe na stanowisku ciernym

- próby hamulcowe podczas jazdy z odczepianiem pojedynczego wagonu, aby wykazać właściwą hamowność wagonu (drogę hamowania) wg karty UIC 544-1 [14]

- próby na pochyleniach toru $40 \%$, przeprowadzone na trasach alpejskich; próba ta ma wykazać funkcjonalność hamulca ręcznego w zakresie wymaganym przez przepisy TSI

- odporność na warunki zimowe została udowodniona za pomocą nadzorowanych prób eksploatacyjnych w Szwecji oraz i w komorze klimatycznej we Wiedniu.
Wstawki typu K oraz LL powinny spełniać wymagania, przedstawione w karcie UIC 541-4 [14].

Jak wynika z przeprowadzonych doświadczeń eksploatacyjnych istotne zmniejszenie poziomu hałasu podczas przejazdu pociagu towarowego można osiagnąc wtedy, gdy ilość wagonów wyposażonych we wstawki z żeliwa fosforowego w składzie wynosi $30 \%$.

Tak więc już na tym etapie można dokonać klasyfikacji możliwych środków zmniejszających emisję hałasu, które są przedstawione w tabeli 4.

Możliwe zmniejszenie emisji halasu za pomocą różnych środków konstrukcyjnych Tabela 4

\begin{tabular}{|c|c|c|c|c|c|}
\hline \multirow[b]{2}{*}{ Oznaczenie kategorii } & \multirow[b]{2}{*}{ Kategoria } & \multirow[b]{2}{*}{ Środek konstrukcyjny } & \multicolumn{3}{|c|}{ Udzial } \\
\hline & & & $\begin{array}{c}\text { Koło } \\
{[\mathrm{dB}(\mathrm{A})]}\end{array}$ & $\begin{array}{c}\text { Tor } \\
{[\mathrm{dB}(\mathrm{A})]}\end{array}$ & $\begin{array}{r}\text { Razem } \\
{[\mathrm{dB}(\mathrm{A})]}\end{array}$ \\
\hline \multirow{2}{*}{$\mathbf{A}$} & \multirow{2}{*}{ Wzbudzenie drgań } & Hamulec tarczowe & -4 & -7 & -6 \\
\hline & & Bardzo niska chropowatość & -6 & -9 & -8 \\
\hline \multirow{4}{*}{ B } & \multirow{4}{*}{$\begin{array}{l}\text { Konstrukcje koła o zmniej- } \\
\text { szonej emisji hałasu }\end{array}$} & $\begin{array}{c}\text { Kolo z elementami tlumią- } \\
\text { cymi }\end{array}$ & $-5 \div 10$ & $\mathbf{0}$ & -1 \\
\hline & & Koło usprężynowane & -8 & $\mathbf{0}$ & -1 \\
\hline & & $\begin{array}{l}\text { Ksztalt koła i jego cechy } \\
\text { geometryczne }\end{array}$ & -8 & $\mathbf{0}$ & -1 \\
\hline & & $\begin{array}{l}\text { Ksztalt koła i jego cechy } \\
\text { geometryczne i tlumienie }\end{array}$ & -12 & $\mathbf{0}$ & -1 \\
\hline \multirow{5}{*}{$\mathbf{C}$} & \multirow{5}{*}{ Konstrukcje toru } & $\begin{array}{c}\text { Optymalna sztywność } \\
\text { mocowania szyny }\end{array}$ & $\mathbf{0}$ & $\mathbf{0}$ & $\mathbf{0}$ \\
\hline & & $\begin{array}{l}\text { Większe thumienie moco- } \\
\text { wania szyny }\end{array}$ & $\mathbf{0}$ & $-2 \div-3$ & -1 \\
\hline & & $\begin{array}{c}\text { Zwiększone tłumienie } \\
\text { szyny }\end{array}$ & $\mathbf{0}$ & -3 & -2 \\
\hline & & Optymalny ksztalt szyny & $\mathbf{0}$ & $0 . .-3$ & $0 \ldots-1$ \\
\hline & & $\begin{array}{c}\text { Optymalny ksztalt szyny } i \\
\text { thumienia }\end{array}$ & $\mathbf{0}$ & -4 & -3 \\
\hline \multirow{4}{*}{ D } & \multirow{4}{*}{$\begin{array}{c}\text { Zmniejszenie przenoszenia } \\
\text { halasu }\end{array}$} & Osłona na wózek & $-3-7$ & $\mathbf{0}$ & -1 \\
\hline & & Niski ekran na szynach & $\mathbf{0}$ & $-3 \ldots-5$ & $-1 \ldots-3$ \\
\hline & & $\begin{array}{l}\text { Niski ekran na szynach i } \\
\text { pochlanianie dźwięku }\end{array}$ & -1 & $-3 \ldots-6$ & $-1 . .-4$ \\
\hline & & $\begin{array}{c}\text { Niski ekran i osłona wóz- } \\
\text { ków }\end{array}$ & -10 & -7 & -7 \\
\hline
\end{tabular}

Możliwe zmniejszenie emisji hałasu za pomocą różnych kombinacji środków konstrukcyjnych

Tabela 5

\begin{tabular}{|c|c|c|c|c|}
\hline \multirow{2}{*}{ Oznaczenie kategorii } & Środek konstrukcyjny & \multicolumn{3}{|c|}{ Udzial } \\
\cline { 2 - 5 } & $\begin{array}{c}\text { Koło } \\
{[\mathrm{dB}]}\end{array}$ & $\begin{array}{c}\text { Tor } \\
{[\mathrm{dB}]}\end{array}$ & $\begin{array}{c}\text { Lącznie } \\
{[\mathrm{dB}]}\end{array}$ \\
\hline B+C & Koło i tor o niskiej emisji halasu & -12 & -4 & -5 \\
\hline B+C+D & $\begin{array}{c}\text { Koło i tor o niskiej emisji halasu oraz } \\
\text { zastosowanie ekranu }\end{array}$ & -20 & -10 & $-10^{*}(-11)$ \\
\hline A+B+C & $\begin{array}{c}\text { Pomniejszona chropowatość i koło } \\
\text { oraz tor o niskiej emisji halasu }\end{array}$ & -18 & -10 & $-11^{*}(-12)$ \\
\hline A+D & $\begin{array}{c}\text { Zmniejszona chropowatość i całkowi- } \\
\text { te ekranowanie }\end{array}$ & -14 & -14 & $-13^{*}(-14)$ \\
\hline A+B+C+D & $\begin{array}{c}\text { Pomniejszona chropowatość } \text { i koło } \\
\text { oraz tor o niskiej emisji halasu }\end{array}$ & -27 & -16 & $-15^{*}(-17)$ \\
\hline
\end{tabular}


Zestawienie środków technicznych zmniejszających emisję hałasu wagonów towarowych wraz wraz z ewentualnymi kosztami ich wprowadzenia

Tabela 6

\begin{tabular}{|c|c|c|c|c|c|}
\hline L.p. & $\begin{array}{l}\text { Środki innowa- } \\
\text { cyjno-techniczne }\end{array}$ & Efekt akustyczny & $\begin{array}{l}\text { Koszty } \\
\text { [Eur] }\end{array}$ & Stan rozwoju & $\begin{array}{c}\text { Możliwość } \\
\text { modernizacji lub dosta- } \\
\text { wy }\end{array}$ \\
\hline 1. & $\begin{array}{l}\text { Szlifowanie szyn } \\
\text { za pomocą spe- } \\
\text { cjalistycznych } \\
\text { pojazdów trak- } \\
\text { cyjno-roboczych }\end{array}$ & $\begin{array}{c}3 \mathrm{~dB}(\mathrm{~A}) \text { w sposób } \\
\text { ciągly }\end{array}$ & $\begin{array}{c}\text { 7Eur/m +koszty } \\
\text { kontroli+ koszty } \\
\text { blokowania linii } \\
\text { kolejowej dla } \\
\text { eksploatacji ko- } \\
\text { mercyjnej }\end{array}$ & $\begin{array}{l}\text { optymalizacja metod } \\
\text { pomiarowych toru oraz } \\
\text { szlifowania szyn }\end{array}$ & \\
\hline 2. & $\begin{array}{l}\text { Wstawki hamul- } \\
\text { cowe typu K } \\
\text { Wstawki hamul- } \\
\text { cowe typu LL }\end{array}$ & $\begin{array}{l}\text { 7-9 } \mathrm{dB}(\mathrm{A}) \text { równy } \\
\text { pod względem } \\
\text { efektu akustycz- } \\
\text { nego hamulcom } \\
\text { tarczowym }\end{array}$ & $\begin{array}{c}\text { Koszty moderni- } \\
\text { zacji wagonu, } \\
\text { wyposażonego we } \\
\text { wstawki typu K- } \\
5000 \text { Eur na } \\
\text { wagon } \\
\text { Koszty moderni- } \\
\text { zacji wagonu } \\
\text { wyposażonego we } \\
\text { wstawki typu LL } \\
\text {-800Eur na wa- } \\
\text { gon }\end{array}$ & $\begin{array}{c}\text { Dopuszczenie UIC, dal- } \\
\text { sze wstawki w próbach } \\
\text { eksploatacji nadzorowa- } \\
\text { nej i w rozwoju }\end{array}$ & $\begin{array}{c}\text { Nowa dostawa wagonów } \\
\text { towarowych oraz mo- } \\
\text { dernizacja istniejących } \\
\text { wagonów }\end{array}$ \\
\hline 3. & $\begin{array}{c}\text { Rozprzężenie } \\
\text { drganiowe po- } \\
\text { między wózkiem } \\
\text { a pudlem wagonu }\end{array}$ & $1 \div 2 \mathrm{~dB}(\mathrm{~A})$ & $\begin{array}{c}\text { Koszty rozwoju } \\
\text { nowych wagonów } \\
\text { towarowych }\end{array}$ & $\begin{array}{l}\text { Techniczne rozwiązanie } \\
\text { istniejących wagonów } \\
\text { towarowych np. podpory } \\
\text { gumowe dla kontenerów }\end{array}$ & $\begin{array}{c}\text { Zastosowanie w specjal- } \\
\text { nych wagonach towaro- } \\
\text { wych }\end{array}$ \\
\hline 4. & $\begin{array}{c}\text { Tlumienie drgań i } \\
\text { akustyczna } \\
\text { optymalizacja } \\
\text { układów biego- } \\
\text { wych }\end{array}$ & $5 \div 6 \mathrm{~dB}(\mathrm{~A})$ & $\begin{array}{c}\text { Koszty rozwoju } \\
\text { wagonu towaro- } \\
\text { wego+250 } \div 1500 \\
\text { Euro w przelicze- } \\
\text { niu na zestaw } \\
\text { kolowy }\end{array}$ & $\begin{array}{l}\text { Wózki i thumienie drgań } \\
\text { koła w dalszym rozwoju }\end{array}$ & $\begin{array}{l}\text { Wózek wyposażony w } \\
\text { elementy gumowo- } \\
\text { metalowe, tlumiki oraz i } \\
\text { elementy tlumiące }\end{array}$ \\
\hline 5. & $\begin{array}{c}\text { Akustyczna } \\
\text { optymalizacja } \\
\text { nadwozi pojaz- } \\
\text { dów oraz } \\
\text { przekładni ha- } \\
\text { mulcowych } \\
\end{array}$ & $1 \div 2 \mathrm{~dB}(\mathrm{~A})$ & $\begin{array}{l}\text { Koszty rozwoju } \\
\text { dla wagonu towa- } \\
\text { rowego }\end{array}$ & $\begin{array}{l}\text { Rozwiązanie techniczne } \\
\text { jest dostępne np. tulejki z } \\
\text { tworzyw sztucznych }\end{array}$ & $\begin{array}{l}\text { Zastosowanie specjal- } \\
\text { nych pojazdów }\end{array}$ \\
\hline 6. & $\begin{array}{c}\text { Osłony na koła } \\
\text { oraz wózki i } \\
\text { ekrany dźwięko- } \\
\text { chłonne o niskiej } \\
\text { wysokości }\end{array}$ & $8 \div 8 \mathrm{~dB}(\mathrm{~A})$ & $\begin{array}{c}8000 \text { Euro/wagon } \\
\text { towarowy } \\
200 \text { Euro/metr }\end{array}$ & $\begin{array}{c}\text { Rozwiązania tylko pro- } \\
\text { totypowe }\end{array}$ & $\begin{array}{l}\text { Obecnie nie jest to moż- } \\
\text { liwe ze względu na wy- } \\
\text { stępowanie urządzeń do } \\
\text { wykrywania przegrza- } \\
\text { nych lożysk tocznych } \\
\text { HOA oraz ze względów } \\
\text { konserwacyjnych }\end{array}$ \\
\hline
\end{tabular}

Z porównania danych tabeli 3 i 4 wynika, że środki konstrukcyjne i ich kombinacje prowadzą do znaczącego obniżenia emisji hałasu do środowiska naturalnego. Środki techniczne, opisane w tabeli 3 i 4 mają charakter ogólnych wytycznych. W tabeli 6 przedstawiono bardziej konkretne rozwiązania w połączeniu $\mathrm{z}$ możliwym obniżeniem emisji hałasu podczas jazdy wagonu towarowego oraz dodatkowe koszty związane $\mathrm{z}$ wprowadzeniem innowacji technicznych.

Powyższe zestawienia nie negują przedsięwzięć, które powinny podjąć służby zarządzające infrastrukturą kolejową poszczególnych państw członkowskich UE, aby zmniejszyć emisję hałasu podczas przejazdu wagonów towarowych. Nie mniej jednak należy wziąć pod uwagę, że koszty budowy ekranów dźwiękochłonnych są bardzo wysokie oraz pogarszają architekturę terenu, co wywołuje niechęć mieszkańców do transportu kolejowego. W przeciwieństwie do koła kolejowego wagonu towarowego oraz innych pojazdów trakcyjnych szyna nie stanowi „struktury skończonej" w sensie matematycznym. Dlatego też jego ruch nie jest modalny, na który składają się częstotliwości własne, ale składa się z następujących po sobie fal. Przy niskich częstotliwościach drgań występują wprawdzie zjawiska rezonansowe np. wywołane zachowaniem się nawierzchni kolejowej, takie jak drgania z powodu sztywności thucznia. Drgania te jednak są dużo silniej thumione niż w przypadku drgań rezonansowych kół. Dyskretna budowa lokalizacji szyn kolejowych ze wskazaniem na odległość pomiędzy podkładami kolejowymi prowadzi do efektów rezonansowych przy określonych częstotliwościach, podczas gdy połowa długości fali odpowiada odległości pomiędzy podkładami kolejowymi. W wielu przypadkach wystarcza, aby zastosować model podparty w sposób ciągły, aby obliczyć wartość średnią ciśnienia 
akustycznego i to przede wszystkim wtedy, gdy mocowanie szyny nie jest za sztywne. Przy wystepowaniu dużych zakresów częstotliwości deformacji ulega jedynie przekrój szyny. Dlatego też zwykłe modele belkowe, dające częstotliwości powyżej $1000 \mathrm{~Hz}$ nie są wystarczające. Osłabienie fali każdego typu za pomocą odległości pomiędzy podkładami jest ważnym parametrem dla określenia całego ciśnienia akustycznego, w tym również emisji hałasu szyny. Im mniejsze jest to osłabienie, tym większa jest efektywna powierzchnia szyny, emitująca hałas. Często emisję hałasu i toru wyznacza się z obliczonych drgań i stopni rozprzestrzeniania się hałasu. Stopnie promieniowania hałasu mogą być wyprowadzone $\mathrm{z}$ wyrażeń analitycznych i obliczeń elementów skrajnych. Pojedyncze udziały hałasu na przykładzie obliczeniowym są przedstawione na rys.6.

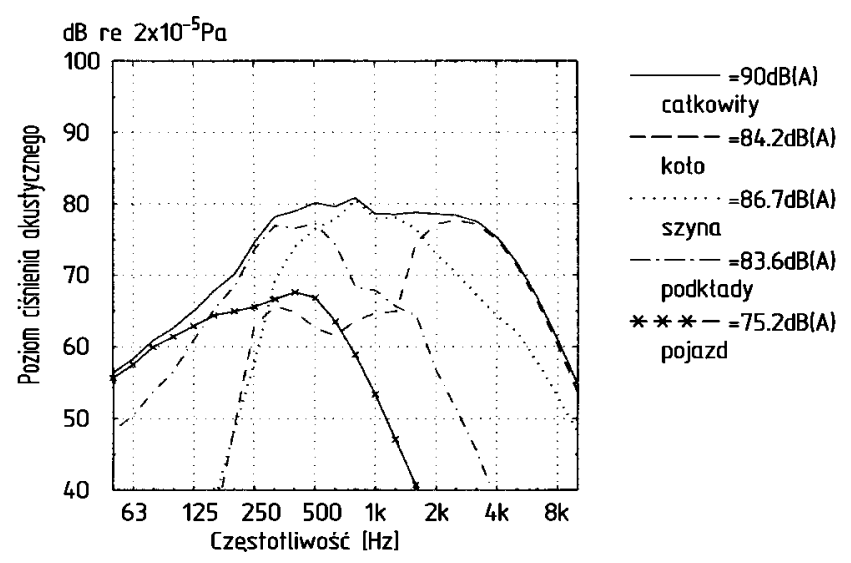

Rys.6. Obliczone udziały ciśnienia akustycznego koła, szyny, podkładów kolejowych i nadwozia wagonu towarowego dla pociagu towarowego na zwykłym torze kolei holenderskich NS (dla prędkości $100 \mathrm{~km} / \mathrm{h}$ i podkładów betonowych) wg [9]

Jednym z rozwiązań technicznych, prowadzących do zmniejszenia emisji hałasu jest szlifowanie szyn [6]. Sukcesy w tej dziedzinie odnotowano już w 1954 ro$\mathrm{ku}$, które doprowadziły do tego, że główne trasy kolejowe były regularnie obsługiwane przez pojazdy trakcyjne do szlifowania szyn.

Szlifowanie szyn daje oprócz zmniejszenia emisji hałasu następujące korzyści:

$>$ przedłużenie żywotności ułożenia szyn w torze

$>$ zwiększenie czasu pomiędzy okresami naprawczymi

$>$ polepszenie komfortu jazdy pojazdów.

Celem szlifowania szyn jest:

$>$ usunięcie uszkodzeń powierzchni jezdnej, wynikających z eksploatacji nawierzchni kolejowej; w tym przypadku chodzi o ślady uszkodzeń spowodowane tłuczniem na powierzchni jezdnej szyny, które inicjują dalsze uszkodzenia i które muszą być usunięte dla optymalnej trwałości szyny
$>$ usunięcie warstwy wierzchniej, zawierającej niską zawartość węgla $\mathrm{w}$ wyniku procesu produkcji; warstwa ta posiada $\mathrm{w}$ praktyce głębokość $0,15 \div 0,30 \mathrm{~mm}$, która powstała przy ogrzewaniu kęsiska kwadratowego do temperatury walcowania przez utlenianie węgla znajdującego się $\mathrm{w}$ pobliżu powierzchni. Jak wynika $\mathrm{z}$ praktyki $\mathrm{w}$ rezultacie usunięcia warstwy wierzchniej o małej zawartości węgla proces tworzenia się rowków na szynie może przesunąć się w czasie.

$>$ wytworzenie równomiernego profilu główki szyny, uwzględniając sytuację zabudowy szyny.

Koszty szlifowania szyn szacuje się na $4,40 \div 5,05$ $\mathrm{EUR} / \mathrm{m}$ w zależności od zebranej ilości jej materiału. W przypadku szlifowania szyn, znajdujących się na łukach koszty te wzrastają do około $28 \mathrm{EUR} / \mathrm{m}$, przy czym uwzględnione są $\mathrm{w}$ tym przypadku koszty prac wstępnych oraz koszty materiałowe.

Przez nierówności szyny rozumie się okresowe nierówności profilu główki szyny z typowymi długościami fal od $10 \div 30 \mathrm{~mm}$, które powstają $\mathrm{w}$ wyniku dynamicznego oddziaływania układu koło-szyna i procesu zużycia. Rozróżnia się w tym przypadku:

$>$ rowki $\mathrm{z}$ długościami fal zużyciowych od $10 \div 100 \mathrm{~mm}$

$>$ fale poślizgu o długościach od $30 \div 300 \mathrm{~mm}$.

Kolejnym etapem rozwoju tej technologii jest tzw. „szlifowanie oscylacyjne”, opracowane przez Schweerbau GmbH, Stadthagen.

Nierówności na powierzchni jezdnej nie ograniczają funkcji jezdnych oraz nośnych szyny. Jednakże one zwiększają obciążenie dynamiczne pojazdu i toru kolejowego. Obciążenie, wynikające z drgań prowadzi do przyspieszonego uszkodzenia pojazdu i toru kolejowego. Wypadkowe obciazżenie, spowodowane drganiami prowadzi do przyspieszonego procesu uszkodzeń szyn, ich mocowania, podkładów kolejowych i thucznia oraz zwiększa nakłady finansowe, które trzeba ponieść na konserwacje i naprawy. Nierówności na powierzchni jezdnej zmniejszają komfort jazdy i zwiększają emisję hałasu i drgań oraz przyczyniają się do zmniejszenia akceptacji transportu szynowego u klientów i właścicieli taboru kolejowego i infrastruktury kolejowej. W celu uwidocznienia oddziaływania nierówności powierzchni jezdnej na obciążenie poszczególnych komponentów nawierzchni kolejowej maksymalne przyspieszenie $\mathrm{w}$ kierunku pionowym wyraża się następującą zależnością:

gdzie:

$$
\ddot{z}=a\left(\frac{2 \pi}{L} \cdot v\right)^{2}
$$

L-długość fali

v-prędkość pojazdu

a-głębokość nierówności mającej kształt sinusoidalny. 
Przyspieszenie, wyrażone wzorem (2) jest źródłem nie tylko drgań i dodatkowych obciążeń dynamicznych, ale również źródłem emisji hałasu do środowiska naturalnego.

W związku z powyższymi rozważaniami kolej niemiecka DB AG wprowadziła do praktyki eksploatacyjnej „tor o szczególnie dobrym stanie utrzymania” (,,besonders überwachtes Gleis” (BüG)). Pojęcie to oznacza zastosowanie prewencyjnych środków konserwacyjnych szyn, aby ograniczyć emisję hałasu do środowiska naturalnego. W wyniku bardzo dokładnej i regularnej kontroli stanu szyn podłużne wyżłobienia, będące źródłem hałasu, mogą być wcześniej wykryte i usunięte. Zobowiązanie się użytkownika infrastruktury do dokładnej kontroli odcinka toru kolejowego zmniejsza emisję hałasu o około $3 \mathrm{~dB}(\mathrm{~A})$. Tor kolejowy „BüG” należy do aktywnych środków zwalczania hałasu i pozwala na utrzymanie wartości granicznych emisji hałasu i na rezygnację $z$ konstrukcji budowlanych np. ekranów dźwiękochłonnych. W Niemczech obecnie występują odcinki toru „BüG” o łącznej długości $1000 \mathrm{~km}$. Kontrola toru „B̈̈G” odbywa się co pół roku za pomocą wagonów własnej konstrukcji do pomiaru emisji hałasu.

\subsection{Koło z tlumikiem hałasu}

Aby zmniejszyć emisję hałasu pochodzącą od układów biegowych wagonów towarowych, można zastosować koło $\mathrm{z}$ thumikiem hałasu. Wychodząc $\mathrm{z}$ założenia, że głównym źródłem hałasu jest układ kołoszyna, a na kole tarcza koła, jednym z rozwiązań zmniejszającym emisję hałasu jest thumik, wykonany $\mathrm{z}$ materiałów kompozytowych o konstrukcji typu „sandwich". Tłumik ten jest wmontowany w konstrukcję koła za pomocą pierścienia metalowego. Lepszym rozwiązaniem z punktu widzenia ograniczenia emisji hałasu byłoby zastosowanie tłumika hałasu z obydwu stron. Jak wynika $\mathrm{z}$ przeprowadzonych pomiarów hałasu spodziewane zmniejszenie emisji hałasu wynosi ok. $2 \div 3 \mathrm{~dB}(\mathrm{~A})$ przy prędkości przejazdu $80 \mathrm{~km} / \mathrm{h}$. Jednak strona zewnętrzna koła jest wykorzystywana do przetaczania zarysu zewnętrznego koła, wskutek procesu zużycia powierzchni tocznej oraz obrzeża. Koło to jest przedstawione na rys. 7 .

Rys.7. Koło z thumikiem hałasu od strony wewnętrznej,

wyprodukowane przez

firmę Bonatrans (Czechy)
Powyższe koło jak i inne koła monoblokowe muszą spełniać warunki wytrzymałości statycznej i zmęczeniowej zgodnie z PN-EN 13 979+A1:2009 [18].

\section{ZAKOŃCZENIE}

Walka z hałasem jest przedsięwzięciem kosztownym i technicznie trudnym, któremu musi sprostać nowoczesny transport kolejowy ładunków. Aby jednak to spełnić i utrzymać konkurencyjność transportu kolejowego ładunków konieczne jest wprowadzenie środków konstrukcyjnych zmniejszających emisję hałasu. Gwarantuje to spełnienie warunków interoperacyjności przez wagony towarowe zgodnie z przepisami TSI [19].Warto nadmienić, że na kolejach DB AG tylko w roku 2000 udało się przetransportować tylko 76 miliardów tonokilometrów ładunków drogą kolejowa, natomiast transportem drogowym $374 \mathrm{mi}-$ liardy tonokilometrów. W transporcie kolejowym ładunków odnotowano w ostatnich latach zmniejszający się udział na rynku kolejowym taboru bezpiecznego i przyjaznego dla środowiska, pomimo stale rosnących wskaźników przewozowych na przestrzeni poszczególnych lat. Istotnym ograniczeniem dla rozwoju nowoczesnych środków konstrukcyjnych, zmniejszających emisję hałasu jest rachunek ekonomiczny. To on spowodował, że wózki typu Y37 z hamulcami tarczowymi nie weszły do produkcji seryjnej na skalę europejska, pomimo że uznane zostały jako standardowe, a tym samym przystosowane do ruchu transgranicznego przez Grupe Roboczą ORE/ERRI, a następnie przez UIC. Wysokie koszty ultralekkiego wózka LEILA-DB spowodowały, że nie wszedł on w ogóle do produkcji seryjnej, pomimo bardzo dobrych parametrów technicznych, które zostały osiagnięte podczas badań homologacyjnych. Tendencja do stosowania wózków wagonów towarowych przystosowanych do prędkości $120 \mathrm{~km} / \mathrm{h} \mathrm{w}$ stanie próżnym i $100 \mathrm{~km} / \mathrm{h}$ w stanie ładownym, co z góry eliminuje wózek Y37 z zastosowania $\mathrm{w}$ masowej eksploatacji komercyjnej, jak na razie, eliminuje wózek Y37 z zastosowania w masowej eksploatacji komercyjnej, który jest dostosowany do $160 \mathrm{~km} / \mathrm{h} \mathrm{z}$ naciskiem maksymalnym zestawu kołowego na tor wynoszącym 18 ton. Pewnym rozwiązaniem, zachęcającym użytkowników taboru kolejowego do stosowania środków konstrukcyjnych zmniejszających emisję hałasu jest program odpłatności przez infrastrukturę kolejową dla tych użytkowników taboru, którzy wykazują mały poziom emisji hałasu do środowiska naturalnego podczas eksploatacji komercyjnej. Program ten został opracowany przez koleje austriackie ÖBB. Program informatyczny, w którym zebrane są konfiguracje o poszczególnych pociagach i pojazdach o nazwie ARTIS (Austrian Rail Transport Information System) [7]. Warunkiem 
odpłatności dla użytkowników pojazdów (wagonów towarowych) jest pełne monitorowanie przejazdów pociagów na trasach. Punktem wyjściowym jest prędkość bazowa do pomiaru hałasu wynosząca $80 \mathrm{~km} / \mathrm{h}$. Tak więc $\mathrm{w}$ przypadku budowy nowych wagonów towarowych konieczne będzie zastosowanie układów biegowych typu Y25Ls1-K, wyposażonych we wstawki z tworzywa sztucznego, natomiast w przypadku już eksploatowanych wagonów towarowych konieczne będzie zastapienie wstawek z żeliwa fosforowego P10 na wstawki LL. W tym ostatnim przypadku koszty modernizacji nie są wysokie. Modernizacja wagonów już eksploatowanych, polegająca na wyposażaniu ich we wstawki typu $\mathbf{K}$ zamiast wstawek z żeliwa fosforowego jest kosztowna i wymaga modernizacji układu hamulcowego na wózku (pojedyncza obsada) oraz na wagonie. W związku z tym ten kierunek rozwojowy spowalniaja względy ekonomiczne. Nie można wykluczyć, że aby osiągnąć odczuwalny efekt dla ochrony środowiska naturalnego, konieczne jest również podjęcie inwestycji w kierunku ograniczenia hałasu przez użytkowników (właścicieli) infrastruktury.

\section{LITERATURA}

[1] Danzer P.: Die Wirtschaftlichkeit innovativer Güterwagendrehgestelle am Beispiel des Drehgestells LEILA.ZEVrail Glasers Annalen Nr.128.Marzec 2004.

[2] Gasowski W.: Aerodynamika pociagu. Wyd. ITE Radom 1998.

[3] Gessner R.: Schienenverkehrslärm-Senkung der Rad/ Schiene-Geräusche. Eisenbahningenieur Nr. 6/2002

[4] Hartleben D.: Lärminderung durch oszillierendes Schleifen. ZEVrail-Glassers Annalen Nr.129. Sierpień 2005.

[5] Hecht M., Schirmer A.: Leichtes und lärmarmes Güterwagen-Drehgestell (LEILA-DG). Eisenbahntechnische Rundschau.Wrzesień 2003.

[6] Hempe T., Siefer T.: Schienenschleifen als Bestandteil einer technisch -wirtschaftlichen Gleisinstandhaltung. ZEV-Glassers Annalen Nr.131. Marzec 2007.

[7] Kalivoda M., Hierzer R., Ostermann N.: Das Infrastrukturpegel als Steuermechanismus zur Reduzierung des Eisenbahnlärms. ETR-Eisenbahntechnische Rundschau Nr.5/2006.

[8] Paukert H.: Verbundstoffbremssohlen als Ersatz für Grauguss. Aktivitäten der UIC zur Lärmminderung des Eisenbahngüterverkehrs. ZEVRail-Glassers Annalen Nr.131.Marzec 2007
[9] Thompson D., Jansens M., Dittrich M.: Rollgeräusche durch den Rad/Schiene-Kontakt-Beurteilung von Minderungsmassnahmen. ZEV+DET Glassers Annalen Nr. 2/3 Luty-Marzec.1997.

[10] Forum Technika i Badania. Grupa Robocza 7 „Hamulce i uktady biegowe". Zagadnienie UIC 5-110 (4.04.501). Zwalczanie hałasu. Zabudowa wstawek z tworzyw kompozytowych $w$ wagonach towarowych. Wytyczne konstrukcyjne $V$-BKS $(K)$. 8-me wydanie Cześć 1. Konstrukcja i wyposażenie wagonów we wstawki kompozytowe o wysokim wspótczynniku tarcia (K). Część 2. Eksploatacja hamulcowa, kontrola $i$ konserwacja. Ważna od 1.7.2011.

[11] Forum Technika i Badania. Grupa Studialna 5. Hamulce $i$ układy biegowe Zagadnienie UIC 5-110: Zwalczanie hatasu. Zabudowa wstawek z tworzyw kompozytowych $w$ wagonach towarowych. Wytyczne stosowania $V$-BKS(LL).8-me wydanie. Część 1.Konstrukcja wagonów towarowych wyposażonych we wstawki kompozytowe o niskim współczynniku tarcia (LL).Część 2. Eksploatacja hamulca, kontrola $i$ konserwacja. Ważna od 1.07.2011

[12] Karta UIC 432:Wagony towarowe. Prędkości jazdy. Warunki techniczne, które należy spetnić. 11-te wydanie 09/2006.

[13] Karta UIC 510-1: Wagony towarowe. Układ biegowy standaryzacja. 9-te wydanie z 1.01.78. 14-ście zmian od 1.01.80 do 1.01.97.

[14] Karta UIC 541-4: Hamulce. Hamowanie wstawkami klocków hamulcowych z materialu syntetycznego.2gie wydanie z 1.10.1990

[15] Karta UIC 544-1: Hamulec. Hamowność. 4-te wydanie z października 2004 oraz maja 2004.

[16] Karta UIC 832: Warunki techniczne dostawy wstawek hamulcowych z zeliwa fosforowego dla pojazdów trakcyjnych $i$ wagonów. 3-wydanie ze stycznia 2004.

[17] PN-EN ISO 3095: 2005. Kolejnictwo. Pomiar hałasu pojazdów szynowych.

[18] PN-EN 13979-1:A1:2009: Kolejnictwo. Zestawy kołowe $i$ wózki. Koła monoblokowe. Procedura dopuszczenia. Część 1: Koła kute i walcowane.

[19] Przepisy TSI „Decyzja Komisji z dnia 4 kwietnia dotyczqca technicznej specyfikacji interoperacyjności odnoszacej się do podsystemu „,Tabor kolejowyHałas" transeuropejskiego systemu kolei konwencjonalnych (notyfikowana jako dokument $\mathrm{nr}$ C(2011) 658 (tekst majacy znaczenie dla EOG) (2011/229/UE).

[20] Raport ORE/ERRI B12.4: Program rozwoju sprawozdanie $i$ wybór prototypów 2-osiowych wózków wagonów towarowych dla prędkości powyżej 120 $\mathrm{km} / \mathrm{h}$. Wydanie luty 1990

[21] Raport ORE/ERRI B12/Rp.17: Program prób dla wagonów towarowych z podwoziem i struktura wagonu ze stali (które nadaja się do zabudowy automa- 